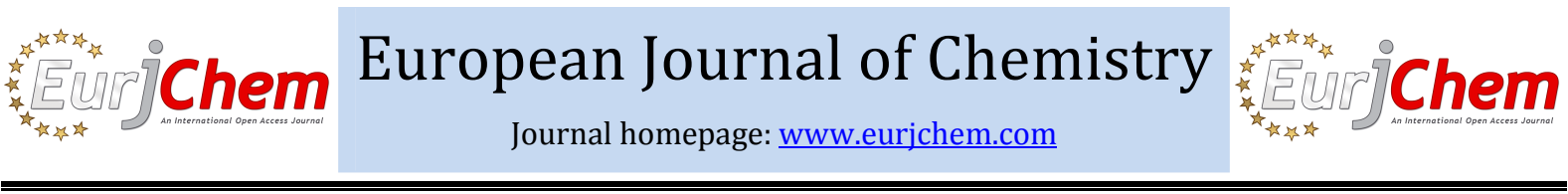

\section{Synthesis and corrosion inhibition evaluation of novel aminic nitrogen-bearing 1,2,4-triazole Schiff base compounds}

\author{
Wael Abdel Gayed Ahmed Arafa a,b,* and Nady Hashem El-Sayed a \\ a Chemistry Department, Faculty of Science, Fayoum University, Fayoum City, 63514, Egypt \\ b Chemistry Department, College of Science, Aljouf University, Sakaka, Aljouf City, 2014, Kingdom of Saudi Arabia \\ ${ }^{*}$ Corresponding author at: Chemistry Department, Faculty of Science, Fayoum University, Fayoum City, 63514, Egypt. \\ Tel.: +2.010.92432679. Fax: +2.084.6370025. E-mail address: waa00@fayoum.edu.eg (W.A.A. Arafa).
}

\section{ARTICLE INFORMATION}

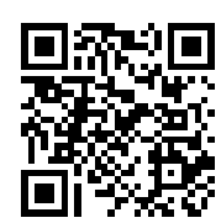

DOI: $10.5155 /$ eurjchem.5.4.563-569.1083

Received: 23 April 2014

Received in revised form: 15 June 2014

Accepted: 15 June 2014

Online: 31 December 2014

\section{KEYWORDS}

EIS

Copper

Inhibitor

Schiff base

Polarization

Heterocycles

\section{Introduction}

Schiff bases are considered privileged compounds, because of their simple preparation. There are several reaction pathways to synthesis Schiff bases. The most common is an acid catalyzed condensation reaction of amine and aldehyde or ketone under refluxing conditions [1,2]. The synthesis of new Schiff base compounds becomes widespread due to their potential application in biological, clinical, analytical and industrial in addition to their important roles in catalysis and organic synthesis [3-8]. In the literature, several Schiff bases have reported as effective corrosion inhibitors for copper and its alloys in acidic media [9-11]. Some researches reveal that the inhibition efficiency of the investigated Schiff bases is much greater than that for corresponding amines and aldehydes [12]. Moreover, the most widely used inhibitors in the field of copper corrosion in chloride containing media are the heterogeneous organic compounds having higher basicity and electron density on the hetero atoms such as nitrogen and sulphur [13,14]. Among these compounds, 1,2,4-triazole, its amino derivatives [15-20], thiophene [21], and pyrazole [22,23] are the most used inhibitors. These molecules normally form a very thin and persistent adsorbed film that block the active sites on the surface and thereby reduce the corrosion rate by slowing down of anodic, cathodic reaction or both $[24,25]$.
In this study, we have further improved inhibition effect of 3-amino-1,2,4-triazole by preparing its Schiff bases with pyrazole-4-carbaldehydes. The synthesized Schiff base molecule, $\quad N$-((1-phenyl-3-(thiophen-2-yl)-1H-pyrazol-5-yl) methylene)-4H-1,2,4-triazol-3-amine (PTP), 5c, has additional $\pi$-bonds as well as a phenyl, pyrazolyl and thienyl moieties which are assumed to be active center of adsorption. Therefore, the molecule is expected to show better adsorption ability and corrosion inhibition efficiency. The inhibition studies of this Schiff base derivative were performed using potentiodynamic polarization and electrochemical impedance. The electrochemical studies of the other two derivatives, $\mathbf{5 a}$ and $\mathbf{5 b}$, will be studied separately.

\section{Experimental}

\subsection{Instrumentation}

${ }^{1} \mathrm{H}$ and ${ }^{13} \mathrm{C}$ NMR spectra were recorded at $400 \mathrm{MHz}$ and at $100 \mathrm{MHz}$, respectively. Chemical shits $(\delta)$ are reported in ppm, using the residual solvent peak $\left(\mathrm{CDCl}_{3} \delta(\mathrm{H})=7.26\right.$ and $\delta(\mathrm{C})=$ 77.16; DMSO- $d_{6} \delta(\mathrm{H})=2.50$ and $\left.\delta(\mathrm{C})=39.52 \mathrm{ppm}\right)$ as internal standard. IR spectra were recorded on a Satellite 2000 spectrometer. 


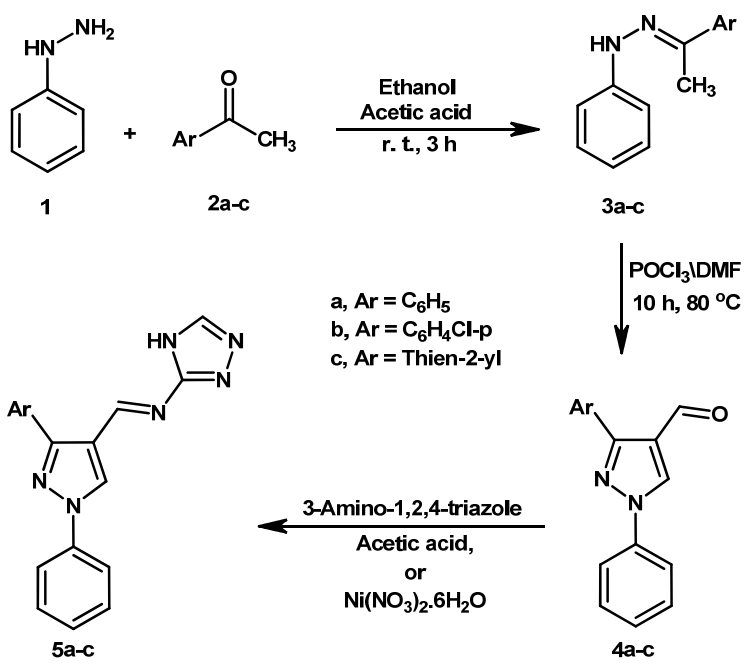

Scheme 1

High resolution mass spectra measurements were recorded on a Bruker Daltonicsmicro TOF spectrometer with an electrospray ionizer. Scanning electron microscopic (SEM) analyses were recorded on model ISPECT S 2006, FEI Company, Holland. Melting points were determined using Stuart electric melting point apparatus and are uncorrected. Reactions are monitored by thin-layer chromatography (TLC) on a silica gel coated aluminum sheet (Silica gel $60 \mathrm{~F}_{254}$ ).

\subsection{Synthesis of phenylhydrazone derivatives (3a-c)}

Phenylhydrazine $(10 \mathrm{mmol})$ in glacial acetic acid $(1 \mathrm{~mL})$ were added to a solution of acetyl derivatives namely, acetophenone, $p$-chloroacetophenone and 2-acetyl thiophene $(10 \mathrm{mmol})$ in $30 \mathrm{~mL}$ of ethanol. Then, the reaction mixture was stirred for $3 \mathrm{~h}$ at room temperature. The precipitate was filtered, washed with cold ethanol and recrystallized from ethanol (Yields: 70-88\%) (Scheme 1).

1-Phenyl-2-(1-phenylethylidene)hydrazine (3a): Color: White. Yield: $85 \%$. M.p.: 104-106 ${ }^{\circ} \mathrm{C}$. FT-IR $\left(\mathrm{KBr}, v_{\max }, \mathrm{cm}^{-1}\right)$ : $3200(\mathrm{~N}-\mathrm{H}), 3054(\mathrm{C}-\mathrm{H}$, arom $), 2922\left(\mathrm{C}-\mathrm{H}, \mathrm{CH}_{3}\right), 1607(\mathrm{C}=\mathrm{N})$, $1589(\mathrm{C}=\mathrm{C}) .{ }^{1} \mathrm{H}$ NMR $\left(400 \mathrm{MHz}, \mathrm{CDCl}_{3}, \delta, \mathrm{ppm}\right): 7.83(\mathrm{~m}, 2 \mathrm{H}$, $\mathrm{ArH}), 7.34(\mathrm{~m}, 8 \mathrm{H}, 7 \mathrm{ArH}, \mathrm{NH}), 6.85(\mathrm{t}, J=7.2 \mathrm{~Hz}, 1 \mathrm{H}, \mathrm{ArH}), 2.22$ $\left(\mathrm{s}, 3 \mathrm{H}, \mathrm{CH}_{3}\right) .{ }^{13} \mathrm{C}$ NMR $\left(100 \mathrm{MHz}, \mathrm{CDCl}_{3}, \delta, \mathrm{ppm}\right): 144.6(1 \mathrm{C}$, $\mathrm{N}=\mathrm{CH}$ ), 141.2 (1C, Ar-C), 138.3 (1C, Ar-C), 130.3 (1C, Ar-C), 129.5 (2C, Ar-C), 128.9 (2C, Ar-C), 124.2 (1C, Ar-C), 122.0 (2C, $\mathrm{Ar}-\mathrm{C}), 114.2$ (2C, Ar-C), $11.0\left(1 \mathrm{C}, \mathrm{CH}_{3}\right)$. MS $(\mathrm{m} / \mathrm{z})$ : Calcd. for $\mathrm{C}_{14} \mathrm{H}_{14} \mathrm{~N}_{2}: 210.1157$, found: 210.1145 .

2-(1-(4-Chlorophenyl)ethylidene)-1-phenylhydrazine (3b): Color: Light yellow. Yield: $88 \%$. M.p.: $135-136^{\circ} \mathrm{C}$. FT-IR (KBr, $\left.v_{\max }, \mathrm{cm}^{-1}\right): 3233(\mathrm{~N}-\mathrm{H}), 3032\left(\mathrm{C}-\mathrm{H}\right.$, arom) $2911\left(\mathrm{C}-\mathrm{H}, \mathrm{CH}_{3}\right)$, $1613(\mathrm{C}=\mathrm{N}), 1597(\mathrm{C}=\mathrm{C}) .{ }^{1} \mathrm{H}$ NMR $\left(400 \mathrm{MHz}, \mathrm{CDCl}_{3}, \delta, \mathrm{ppm}\right)$ : $7.81(\mathrm{~d}, J=8.2 \mathrm{~Hz}, 2 \mathrm{H}, \mathrm{ArH}), 7.30(\mathrm{~m}, 3 \mathrm{H}, 2 \mathrm{ArH}$ and $\mathrm{NH}), 7.21$ (m, 4H, ArH), $6.93(\mathrm{~m}, 1 \mathrm{H}, \mathrm{ArH}), 2.19\left(\mathrm{~s}, 3 \mathrm{H}, \mathrm{CH}_{3}\right) .{ }^{13} \mathrm{C}$ NMR $(100$ $\mathrm{MHz}, \mathrm{CDCl}_{3}, \delta, \mathrm{ppm}$ ): 144.3 (1C, N=CH), 140.4 (1C, $\left.\mathrm{Ar}-\mathrm{C}\right), 138.8$ (1C, Ar-C), 136.0 (2C, Ar-C), 129.1 (2C, Ar-C), 129.2 (2C, Ar-C), 124.4 (1C, Ar-C), 121.0 (1C, Ar-C), 115.0 (2C, Ar-C), 11.3 (1C, $\left.\mathrm{CH}_{3}\right)$. MS $(\mathrm{m} / \mathrm{z})$ : Calcd. for $\mathrm{C}_{14} \mathrm{H}_{13} \mathrm{ClN}_{2}$ : $244.0767 / 246.0738$ found: $244.0762 / 246.0734$.

1-Phenyl-2-(1-(thiophen-2-yl)ethylidene)hydrazine (3c): Color: Yellow. Yield: $70 \%$. M.p.: $155-157{ }^{\circ} \mathrm{C}$. FT-IR (KBr, $v_{\max }$, $\left.\mathrm{cm}^{-1}\right): 3202(\mathrm{~N}-\mathrm{H}), 3049(\mathrm{C}-\mathrm{H}$, arom), $2972(\mathrm{C}-\mathrm{H}, \mathrm{CH} 3), 1622$ $(\mathrm{C}=\mathrm{N}), 1577(\mathrm{C}=\mathrm{C}) .{ }^{1} \mathrm{H}$ NMR $\left(400 \mathrm{MHz}, \mathrm{CDCl}_{3}, \delta, \mathrm{ppm}\right): 8.01(\mathrm{dd}$, $J=2.5 \mathrm{~Hz}, J=1.7,1 \mathrm{H}, \mathrm{Th} \mathrm{H}-5), 7.77(\mathrm{~m}, 2 \mathrm{H}, \mathrm{Ar}-\mathrm{H}), 7.35$ (dd, $J=$ $2.5 \mathrm{~Hz}, J=1.5 \mathrm{~Hz}, 1 \mathrm{H}, \mathrm{Th} \mathrm{H}-4), 7.22(\mathrm{~m}, 3 \mathrm{H}, \mathrm{Ar}-\mathrm{H}$ and $\mathrm{NH}), 7.05$ (dd, $J=5.0 \mathrm{~Hz}, \mathrm{~J}=3.0,1 \mathrm{H}, \mathrm{Th} \mathrm{H}-3), 6.89(\mathrm{~m}, 1 \mathrm{H}, \mathrm{Ar}-\mathrm{H}), 2.33$ (s, $\left.3 \mathrm{H}, \mathrm{CH}_{3}\right) .{ }^{13} \mathrm{C}$ NMR $\left(100 \mathrm{MHz}, \mathrm{CDCl}_{3}, \delta, \mathrm{ppm}\right): 145.2(1 \mathrm{C}, \mathrm{N}=\mathrm{CH})$, 143.1 (1C, Ar-C), 129.4 (1C, Ar-C), 128.5 (2C, Ar-C), 127.6 (1C, Ar-C), 127.2 (1C, Ar-C), 126.2 (1C, Ar-C), 123.9 (1C, Ar-C), 116.1 (2C, Ar-C), $12.3\left(1 \mathrm{C}, \mathrm{CH}_{3}\right)$. MS $(\mathrm{m} / \mathrm{z})$ : Calcd. for $\mathrm{C}_{12} \mathrm{H}_{12} \mathrm{~N}_{2} \mathrm{~S}$ : 216.0721, found: 216.0724 .

\subsection{Synthesis of 3-aryl-1-phenyl-1H-pyrazole-4- carbaldehyde (4a-c)}

A mixture of DMF $(2.58 \mathrm{~g}, 35.30 \mathrm{mmol})$ and $\mathrm{POCl}_{3}(5.40 \mathrm{~g}$, $35.30 \mathrm{mmol}$ ) was cooled at $0{ }^{\circ} \mathrm{C}$ before being stirred at that temperature. A solution of phenylhydrazones 3a-c (11.76 $\mathrm{mmol}$ ) in DMF (5 mL) was added dropwise to the reaction mixture which was then warmed at room temperature and heated at $80^{\circ} \mathrm{C}$ for $10 \mathrm{~h}$. After cooling at room temperature, the resulting mixture was poured onto crushed ice, neutralized with cold potassium carbonate solution and left standing overnight. The precipitate was filtered, washed with water $(5 \times$ $20 \mathrm{~mL}$ ) and crystallized from ethanol (Scheme 1).

1,3-Diphenyl-1H-pyrazole-4-carbaldehyde (4a): Color: Light yellow. Yield: $88 \%$. M.p.: $141-142{ }^{\circ} \mathrm{C}$. FT-IR $\left(\mathrm{KBr}, v_{\max }, \mathrm{cm}^{-1}\right)$ : 3118 (C-H, arom), 1677 (C=0) (aldehyde), 1601 (C=N), 1582 $(\mathrm{C}=\mathrm{C}) .{ }^{1} \mathrm{H}$ NMR $\left(400 \mathrm{MHz}, \mathrm{CDCl}_{3}, \delta, \mathrm{ppm}\right): 10.22(\mathrm{~s}, 1 \mathrm{H}, \mathrm{CHO}$ ), 8.54 (s, 1H, Py H-5), 7.89 (m, 2H, Ar-H), 7.83 (m, 2H, Ar-H), $7.51(\mathrm{~m}, 5 \mathrm{H}, \mathrm{Ar}-\mathrm{H}), 7.38(\mathrm{~m}, 1 \mathrm{H}, \mathrm{Ar}-\mathrm{H}) .{ }^{13} \mathrm{C}$ NMR $(100 \mathrm{MHz}$ $\mathrm{CDCl}_{3}, \delta, \mathrm{ppm}$ ): 185.4 (1C, CO), 154.6 (1C, Ar-C), 139.0 (1C, ArC), 131.6 (1C, Ar-C), 131.1 (1C, Ar-C), 129.8 (2C, Ar-C), 129.3 (2C, Ar-C), 129.0 (1C, Ar-C), 128.6 (1C, Ar-C), 128.2 (2C, Ar-C), 122.2 (1C, Ar-C), 119.6 (2C, Ar-C). MS (m/z): Calcd. for $\mathrm{C}_{16} \mathrm{H}_{12} \mathrm{~N}_{2} \mathrm{O}: 248.0950$, found: 248.0958 .

3-(4-Chlorophenyl)-1-phenyl-1H-pyrazole-4-carbaldehyde (4b): Color: Yellow. Yield: 85\%. M.p.: $170-172{ }^{\circ} \mathrm{C}$. FT-IR (KBr, $\left.v_{\max }, \mathrm{cm}^{-1}\right): 3111(\mathrm{C}-\mathrm{H}$, arom), 1687 (C=0) (aldehyde), 1611 $(\mathrm{C}=\mathrm{N}), 1597$ (C=C). ${ }^{1} \mathrm{H}$ NMR $\left(400 \mathrm{MHz}, \mathrm{CDCl}_{3}, \delta, \mathrm{ppm}\right): 10.25$ (s, $1 \mathrm{H}, \mathrm{CHO}), 8.50$ (s, 1H, Py H-5), $7.83(\mathrm{~m}, 2 \mathrm{H}, \mathrm{Ar}-\mathrm{H}), 7.78(\mathrm{~m}, 2 \mathrm{H}$ $\mathrm{Ar}-\mathrm{H}), 7.77(\mathrm{~m}, 2 \mathrm{H}, \mathrm{Ar}-\mathrm{H}), 7.46(\mathrm{~m}, 1 \mathrm{H}, \mathrm{Ar}-\mathrm{H}), 7.41(\mathrm{~m}, 2 \mathrm{H}, \mathrm{Ar}-$ H). ${ }^{13} \mathrm{C}$ NMR $\left(100 \mathrm{MHz}, \mathrm{CDCl}_{3}, \delta, \mathrm{ppm}\right): 183.1$ (1C, CO), 153.1 (1C, Ar-C), 139.4 (1C, Ar-C), 131.3 (1C, Ar-C), 130.0 (1C, Ar-C), 129.8 (2C, Ar-C), 129.0 (2C, Ar-C), 128.3 (2C, Ar-C), 127.5 (2C, Ar-C), 126.8 (1C, Ar-C), 122.2 (1C, Ar-C), 119.0 (1C, Ar-C). MS $(\mathrm{m} / \mathrm{z})$ : Calcd. for $\mathrm{C}_{16} \mathrm{H}_{11} \mathrm{ClN}_{2} \mathrm{O}$ : 282.0560/284.0530, found: 282.0558/284.0527.

1-Phenyl-3-(2-thienyl)-1H-pyrazole-4-carbaldehyde (4c): Color: Yellow. Yield: $90 \%$. M.p.: $121-122{ }^{\circ} \mathrm{C}$. FT-IR $\left(\mathrm{KBr}, v_{\max }\right.$ $\left.\mathrm{cm}^{-1}\right): 3106(\mathrm{CH}$, arom $), 1678(\mathrm{C}=0)$ (aldehyde), $1604(\mathrm{C}=\mathrm{N})$ $1590(\mathrm{C}=\mathrm{C}) .{ }^{1} \mathrm{H}$ NMR (400 MHz, $\left.\mathrm{CDCl}_{3}, \delta, \mathrm{ppm}\right): 10.22$ (s, $1 \mathrm{H}$, 
CHO), 8.52 (s, 1H, Py H-5), 8.21 (dd, $J=3.0 \mathrm{~Hz}, J=1.2 \mathrm{~Hz}, 1 \mathrm{H}$, Th H-3), $7.81(\mathrm{~m}, 2 \mathrm{H}, \mathrm{Ar}-\mathrm{H}), 7.73$ (dd, $J=5.0 \mathrm{~Hz}, J=1.2 \mathrm{~Hz}, 1 \mathrm{H}, \mathrm{Th}$ $\mathrm{H}-5), 7.56(\mathrm{~m}, 2 \mathrm{H}, \mathrm{Ar}-\mathrm{H}), 7.45(\mathrm{dd}, J=5.0 \mathrm{~Hz}, J=3.0,1 \mathrm{H}$, Th H4), $7.38(\mathrm{~m}, 1 \mathrm{H}, \mathrm{Ar}-\mathrm{H}) .{ }^{13} \mathrm{C}$ NMR $\left(100 \mathrm{MHz}, \mathrm{CDCl}_{3}, \delta, \mathrm{ppm}\right)$ : 185.1 (1C, CO), 149.4 (1C, Ar-C), 139.0 (1C, Ar-C), 133.0 (1C, ArC), 132.6 (1C, Ar-C), 129.4 (2C, Ar-C), 128.3 (1C, Ar-C), 127.8 (1C, Ar-C), 126.5 (1C, Ar-C), 126.2 (1C, Ar-C), 122.8 (1C, Ar-C), 119.3 (2C, Ar-C). MS (m/z): Calcd. for $\mathrm{C}_{14} \mathrm{H}_{10} \mathrm{~N}_{2} \mathrm{OS}$ : 254.0514, found: 254.0512 .

\subsection{Synthesis of $N$-((1-phenyl-3-aryl-1H-pyrazol-5-yl) methylene)-4H-1,2,4-triazol-3-amine (5a-c)}

Method 1: An ethanolic solution of 3-amino-4H-1,2,4triazole $(10 \mathrm{mmol})$ is magnetically stirred in a round bottom flask followed by addition of appropriate substituted aldehydes 4a-c (10 mmol) containing $2-3$ drops of glacial acetic acid. The reaction mixture is then refluxed for $8 \mathrm{~h}$. The resulting solution was cooled to room temperature and the precipitated was filtered, washed with cold ethanol and recrystallized from dioxane (Scheme 1).

Method 2: Mixture of 3-amino- $4 \mathrm{H}-1,2,4$-triazole (10 mmol) and appropriate substituted aldehydes 4 a-c $(10 \mathrm{mmol})$ was placed in an open glass container, $10 \mathrm{~mol} \% \mathrm{Ni}\left(\mathrm{NO}_{3}\right)_{2} \cdot 6 \mathrm{H}_{2} \mathrm{O}$ in $30 \mathrm{~mL}$ ethanol was added. The reaction mixture was stirred at room temperature for 18-25 min. After completion of the reaction (control by TLC experiment), water was added and the product was filtered, washed with water $(3 \times 20 \mathrm{~mL})$, then with ethanol $(3 \times 20 \mathrm{~mL})$, dried and recrystallized from dioxane.

(E)-N-((1,3-diphenyl-1H-pyrazol-5-yl)methylene)-4H-1,2,4triazol-3-amine (5a): According to the general method 2, the reaction of $84 \mathrm{mg}$ of 3-amino- $4 \mathrm{H}-1,2,4$-triazole and $248 \mathrm{mg}$ of 1,3-diphenyl-1H-pyrazole-4-carbaldehyde $\mathbf{4 a}$ furnishes $\mathbf{5 a}$. Color: Yellow. Yield: 94\%. M.p.: $238{ }^{\circ} \mathrm{C}$. FT-IR $\left(\mathrm{KBr}, \nu_{\max }, \mathrm{cm}^{-1}\right)$ : $3122(\mathrm{NH}), 3100\left(\mathrm{C}-\mathrm{H}\right.$, arom), 1608 (C=N), $1588(\mathrm{C}=\mathrm{C}) .{ }^{1} \mathrm{H}$ NMR (400 MHz, DMSO- $\left.d_{6}, \delta, \mathrm{ppm}\right): 9.98(\mathrm{~s}, 1 \mathrm{H}, \mathrm{NH}), 8.76(\mathrm{~s}, 1 \mathrm{H}$, $\mathrm{CH}=\mathrm{N}$ ), 8.51 (s, 1H, Py H-5), 8.36 (s, 1H, Tri H-5), 7.94 (m, 2H, Ar-H), $7.60(\mathrm{~m}, 2 \mathrm{H}, \mathrm{Ar}-\mathrm{H}), 7.49(\mathrm{~m}, 2 \mathrm{H}, \mathrm{Ar}-\mathrm{H}), 7.45(\mathrm{~m}, 1 \mathrm{H}, \mathrm{Ar}-$ $\mathrm{H}), 7.37(\mathrm{~m}, 2 \mathrm{H}, \mathrm{Ar}-\mathrm{H}), 7.32(\mathrm{~m}, 1 \mathrm{H}, \mathrm{Ar}-\mathrm{H}) .{ }^{13} \mathrm{C}$ NMR $(100 \mathrm{MHz}$, DMSO- $d_{6}, \delta, p p m$ ): $160.0(1 \mathrm{C}, \mathrm{N}=\mathrm{CH}), 154.8$ (1C, Ar-C), 151.1 (1C, Ar-C), 145.7 (1C, Ar-C), 140.5 (1C, Ar-C), 134.6 (1C, Ar-C), 130.3 (2C, Ar-C), 129.5 (2C, Ar-C), 128.5 (1C, Ar-C), 127.3 (2C, Ar-C), 126.5 (1C, Ar-C), 126.3 (1C, Ar-C), 119.3 (2C, Ar-C), 118.6 (1C, $\mathrm{Ar}-\mathrm{C})$. MS $(\mathrm{m} / \mathrm{z})$ : Calcd. for $\mathrm{C}_{18} \mathrm{H}_{14} \mathrm{~N}_{6}: 314.1280$, found: 314.1278.

(E)-N-((1-phenyl-3-(4chlorophenyl)-1H-pyrazol-5-yl) methy lene)-4H-1,2,4-triazol-3-amine (5b): According to the general method 2, the reaction of $84 \mathrm{mg}$ of 3-amino- $4 \mathrm{H}-1,2,4$-triazole and $282 \mathrm{mg}$ of 3-(4-chlorophenyl)-1-phenyl-1H-pyrazole-4carbaldehyde $\mathbf{4 b}$ furnishes $\mathbf{5 b}$. Color: Yellow. Yield: $98 \%$. M.p.: $276^{\circ} \mathrm{C}$. FT-IR (KBr, $\left.v_{\max }, \mathrm{cm}^{-1}\right): 3114(\mathrm{NH}), 3098(\mathrm{C}-\mathrm{H}$, arom), $1612(\mathrm{C}=\mathrm{N}), 1579(\mathrm{C}=\mathrm{C}) .{ }^{1} \mathrm{H}$ NMR $\left(400 \mathrm{MHz}, \mathrm{DMSO}-d_{6}, \delta, \mathrm{ppm}\right)$ : $9.94(\mathrm{~s}, 1 \mathrm{H}, \mathrm{NH}), 8.79(\mathrm{~s}, 1 \mathrm{H}, \mathrm{CH}=\mathrm{N}), 8.54(\mathrm{~s}, 1 \mathrm{H}, \mathrm{Py} \mathrm{H}-5), 8.34$ (s, 1H, Tri H-5), 7.90 (m, 2H, Ar-H), 7.59 (m, 2H, Ar-H), 7.46 (m, $3 \mathrm{H}, \mathrm{Ar}-\mathrm{H}), 7.33(\mathrm{~m}, 2 \mathrm{H}, \mathrm{Ar}-\mathrm{H}) .{ }^{13} \mathrm{C}$ NMR (100 MHz, DMSO-d $6, \delta$, ppm): 159.7 (1C, N=CH), 154.6 (1C, $\mathrm{Ar}-\mathrm{C}), 151.4$ (1C, $\mathrm{Ar}-\mathrm{C})$, 145.9 (1C, Ar-C), 140.7 (1C, Ar-C), 133.6 (1C, Ar-C), 133.0 (1C, Ar-C), 130.5 (2C, Ar-C), 129.1 (2C, Ar-C), 128.2 (2C, Ar-C), 126.8 (1C, Ar-C), 126.1 (1C, Ar-C), 119.5 (2C, Ar-C), 118.5 (1C, Ar-C). MS (m/z): Calcd. for $\mathrm{C}_{18} \mathrm{H}_{13} \mathrm{ClN}_{6}: 348.0890 / 350.0861$, found: 348.0895/350.0864.

(E)-N-((1-phenyl-3-(thiophen-2-yl)-1H-pyrazol-5-yl)methy lene)-4H-1,2,4-triazol-3-amine (5c, PTP): According to the general method 2, the reaction of $84 \mathrm{mg}$ of 3 -amino- $4 \mathrm{H}-1,2,4-$ triazole and $254 \mathrm{mg}$ of 1-phenyl-3-thiophen-2-yl-1H-pyrazole5-carbaldehyde 4c furnishes 5c. Color: Yellow. Yield: $97 \%$. M.p.: $198{ }^{\circ} \mathrm{C}$. FT-IR (KBr, $\left.v_{\max }, \mathrm{cm}^{-1}\right): 3126(\mathrm{NH}), 3086(\mathrm{C}-\mathrm{H}, \mathrm{arom})$, $1602(\mathrm{C}=\mathrm{N}), 1581(\mathrm{C}=\mathrm{C}) .{ }^{1} \mathrm{H}$ NMR $\left(400 \mathrm{MHz}, \mathrm{DMSO}-d_{6}, \delta, \mathrm{ppm}\right)$ : $10.01(\mathrm{~s}, 1 \mathrm{H}, \mathrm{NH}), 8.76(\mathrm{~s}, 1 \mathrm{H}, \mathrm{CH}=\mathrm{N}), 8.51(\mathrm{~s}, 1 \mathrm{H}, \mathrm{Py} \mathrm{H}-5), 8.38$ (s, 1H, Tri H-5), $7.94(\mathrm{~m}, 1 \mathrm{H}, \mathrm{Ar}-\mathrm{H}), 7.90$ (m, 1H, Ar-H), 7.51 (d, J $=3.71 \mathrm{~Hz}, 1 \mathrm{H}$, Th H-3), 7.47 (m, 3H, Ar-H and Th H-5); $7.42(\mathrm{~m}$,
$1 \mathrm{H}, \mathrm{Ar}-\mathrm{H}), 7.11(\mathrm{dd}, J=4.99 \mathrm{~Hz}, J=3.71 \mathrm{~Hz}, 1 \mathrm{H}$, Th $\mathrm{H}-4) .{ }^{13} \mathrm{C}$ NMR (100 MHz, DMSO- $\left.d_{6}, \delta, p p m\right): 160.1(1 \mathrm{C}, \mathrm{N}=\mathrm{CH}), 154.3$ (1C, Ar-C), 150.8 (1C, Ar-C), 146.0 (1C, Ar-C), 140.3 (1C, Ar-C), 133.8 (1C, Ar-C), 130.5 (2C, Ar-C), 128.2 (1C, Ar-C), 127.4 (1C, Ar-C), 126.8 (1C, Ar-C), 126.4 (1C, Ar-C), 126.1 (1C, Ar-C), 119.7 (2C, Ar-C), 118.6 (1C, Ar-C). MS (m/z): Calcd. for $\mathrm{C}_{16} \mathrm{H}_{12} \mathrm{~N}_{6} \mathrm{~S}$ : 320.0844 , found: 320.0840 .

\subsection{Potentiodynamic polarization measurements}

The working electrodes were prepared from commercial copper of composition $(0.02 \mathrm{Ni}, 0.004 \mathrm{Mn}, 0.006 \mathrm{Zn}, 0.003 \mathrm{Fe}$, $0.004 \mathrm{Si}$ and Cu balance in mass \%) was prepared in the form of cylindrical rod and mounted into glass tubes of appropriate diameter by epoxy resin leaving a free surface area of $0.2 \mathrm{~cm}^{2}$ to contact the solution as the working electrode. An all glass three-electrode electrochemical cell, with large area platinum counter electrode and saturated calomel reference electrode, SCE, was served as the electrochemical cell. The working electrode was pretreated by mechanical polishing with successsive grade-emery papers up to 2000 grit, rubbing with a smooth polishing cloth, washing with triple distilled water, and then quickly transferred to the cell. All measurements were carried out instagnant, naturally aerated $0.5 \mathrm{M} \mathrm{HCl}$ solution free or containing different concentrations of the inhibitor. The potentiodynamic polarization measurements were performed using an electrochemical workstation (Voltalab 10 PGZ "All-inone" potentiostat/Galvanostat). Thepotentiodynamic experiments were conducted at a scan rate of $10 \mathrm{mV} / \mathrm{s}$. The values of the corrosion potential, Ecorr, and corrosion current density, $\mathrm{i}_{\text {corr }}$, were extrapolated from the potentiodynamic polarization curves.

\subsection{Electrochemical impedance spectroscopy measurements}

The impedance measurements were performed using an electrochemical workstation (Voltalab 10 PGZ "All-inone"potentiostat/Galvanostat). The potentials were measured against and referred to the SCE $\left(E^{\circ}=0.245 \mathrm{~V}\right.$ the standard hydrogen electrode, SHE).The electrode potential was left in the electrolyte to achieve the steady state until, where the potential change did not exceed $0.1 \mathrm{mV} / \mathrm{min}$. This potential was taken as the steady state potential, $E_{\text {ss. }}$ For all EIS measurements, excitation amplitude of $10 \mathrm{mV}$ peak-to-peak in the frequency range from 0.1 to $10^{5} \mathrm{~Hz}$ was used.

\section{Results and discussion}

\subsection{Synthesis and characterization}

Synthesis of intermediates and target compounds were accomplished according to the steps illustrated in Scheme 1.

One of the most important features of this synthetic route is the use of pyrazole-4-carbaldehydes $\mathbf{4 a - c}$ as a key starting material for further transformations. Compounds 4a-c were prepared in two steps. In the first step, a condensation reaction took place between acetyl derivatives 2a-c and phenyl hydrazine, 1. The resulted hydrazone derivatives, 3a-c, were treated with the Vilsmeier-Haack reagent $\left(\mathrm{DMF} / \mathrm{POCl}_{3}\right)$ leading to the corresponding 4-carboxaldehyde functionalized pyrazole ring in almost quantitative yields.

The common procedures for the preparation of Schiff bases (imines) usually need a prolonged reaction time in addition to some drawbacks were observed such as incompletion of reaction, loss of yield and purification problems. Initially, the synthesis of aldimine-type Schiff bases 5a-c was achieved by condensing stoichiometric ratios of 3-amino- $4 \mathrm{H}-1,2,4$-triazole with the differently substituted pyrazole-4-carbaldehydes $\mathbf{4 a - c}$ under reflux in an absolute ethanol and in the presence of few amounts of glacial acetic acid as a catalyst (Scheme 1). This has afforded moderate yield of Schiff bases (73-77\%, Table 1). 
Table 1. Yields of Schiff bases $\mathbf{5 a - c}$ under different reaction conditions.

\begin{tabular}{|c|c|c|c|c|c|}
\hline \multirow[t]{2}{*}{ Compound } & \multicolumn{4}{|l|}{$\mathrm{Ni}\left(\mathrm{NO}_{3}\right)_{2} .6 \mathrm{H}_{2} \mathrm{O}$} & \multirow{2}{*}{\begin{tabular}{|l|} 
Acetic acid \\
Yield (\%)
\end{tabular}} \\
\hline & 5 mole $\%$, Yield (\%) & 10 mole $\%$, Yield (\%) & 15 mole $\%$, Yield (\%) & Time (min) & \\
\hline $5 a$ & 80 & 94 & 95 & 25 & 75 \\
\hline $5 b$ & 85 & 98 & 98 & 18 & 77 \\
\hline $5 c(\mathrm{PTP})$ & 82 & 97 & 98 & 20 & 73 \\
\hline
\end{tabular}

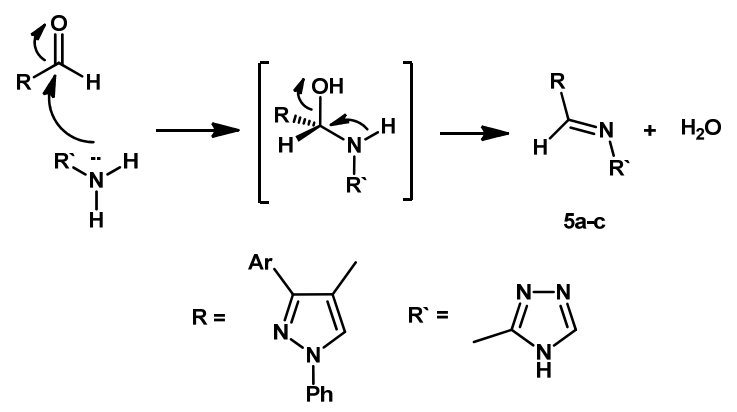

Scheme 2

The obtained products $\mathbf{5 a - c}$ were used as TLC standard for the observation of synthesis of Schiff bases at new synthesis condition. Better conversions and therefore excellent isolated yields were observed when nickel(II) nitrate hexahydrate was used as a catalyst (Table 1). In our new method, Schiff base derivatives 5a-c were synthesized by the reaction between 3amino-4H-1,2,4-triazole and various pyrazole-4-carbaldehydes 4a-c in the presence of nickel(II) nitrate hexahydrate a catalyst and at room temperature in excellent yields.

As presented in Table 1, moderate yields (73-77\%) were observed in the presence of acetic acid as a catalyst. These moderate yields may be due to the amine is mostly protonated in acidic conditions and thus cannot function properly as a nucleophile and the reaction cannot proceed completely [26]. However, by the addition of 5 mole\% nickel(II)nitrate hexahydrate the reaction yields were improved (82-85\%). Most significantly, the highest yields (94-98\%) were obtained when using 10 mole \% of that catalyst. No significant improvement in the reaction yield was observed by increasing the amount of nickel (II) nitrate hexahydrate more than 10 mole \%. An interpretation of yield enhancement is that of nickel(II) nitrate hexahydrate, Lewis acid, which might facilitate both the polarization of the carbonyl group and the removal of water molecule (Scheme 2).

The formation of an imine molecule has been proposed to proceed by a stepwise-mechanism [27-29] (Scheme 2). The first step in this reaction is an attack of nucleophilic nitrogen atom of amine on the carbonyl carbon, resulting in a normally unstable carbinolamine intermediate. At the second step, the deprotonation of the nitrogen in a carbinolamine molecule takes place, and then, the oxygen from the $\mathrm{OH}$ group is pushed off of the carbon by the electrons from the $\mathrm{N}-\mathrm{H}$ bond. This finally results with the $\mathrm{C}=\mathrm{N}$ double bond formation to yield an imine compound, with concomitant loss of a water molecule.

In the present work, a series of three new Schiff bases was synthesized and the structure of the synthesized compounds was established on the basis of IR spectra, NMR and mass spectral data. The IR spectra of compounds 5a-c showed the presence of a strong band in the region of $3126-3114 \mathrm{~cm}^{-1}$ for typical NH stretching bands. The absorption bands around $3090 \mathrm{~cm}^{-1}$ are assigned to the aromatic $\mathrm{C}-\mathrm{H}$ stretch. The appearance of a medium to strong absorption band around $1600 \mathrm{~cm}^{-1}$ is due to the stretching vibration of $\mathrm{C}=\mathrm{N}$ bond formation in the synthesized compounds. The proton spectral data of compounds $\mathbf{4 a - c}$ showed resonance around $\delta 10.2 \mathrm{ppm}$ (s, $1 \mathrm{H}, \mathrm{CHO}$ ). In all the synthesized compounds, 5a-c, the above resonance disappeared and additional resonances assigned to the $-\mathrm{C} H=\mathrm{N}-(\delta 8.79-8.76 \mathrm{ppm})$ was observed, which confirmed the condensation reaction between the amino group and carbonyl group. The mass spectra showed molecular ion peak, which is in agreement with the molecular formula.

\subsection{Effect of $N$-((1-phenyl-3-(thiophen-2-yl)-1H-pyrazol-5- yl)methylene)-4H-1,2,4-triazol-3-amine (PTP), on corrosion behavior of copper in $0.5 \mathrm{M} \mathrm{HCl}$ solution}

\subsubsection{Potentiodynamic polarization measurements}

The potentiodynamic polarization curves of the copper electrode after immersion for $1 \mathrm{~h}$ in $0.5 \mathrm{M} \mathrm{HCl}$ solution containing different concentrations of PTP are shown in Figure 1. It is clear that the presence of PTP in the electrolyte decreases the current density of the $\mathrm{Cu}$-electrode to large extant which can be attributed to the higher adsorption of PTP on the electrode surface. The inhibitor molecules establish their inhibition action via the adsorption on the active corrosion sites of the electrode surface. The adsorption process is affected by the chemical structures of the inhibitor, the nature and charge of the corroding surface [30]. This is a consequence of the fact that the corroding $\mathrm{Cu}$ surface to be inhibited is usually oxide-free, allowing the inhibitor ready access to retard the cathodic and/or the anodic electrochemical reactions. The adsorbed inhibitor molecule may not cover the entire metal surface, but occupies sites which are electrochemically active and thereby reduces the extent of anodic or cathodic reaction or both. The corrosion rate will be decreased in proportion to the extent to which the electrochemically active sites are blocked by the adsorbed inhibitor. PTP inhibits the anodic process to large extant at low concentration and its ability as an excellent corrosion inhibitor is due to the lone pair of electrons on nitrogen and sulfur atoms. The inhibition efficiency is increased as the adsorption of the inhibitor molecules is enhanced with increasing the inhibitor concentration.

The electrochemical parameters such as corrosion current density, $i_{\text {corr, }}$ corrosion potential, $E_{\text {corr }}$ cathodic Tafel slopes, $\beta \mathrm{c}$, anodic Tafel slopes, $\beta \mathrm{a}$, and the inhibition efficiency, $\eta \%$, are given in Table 2. The inhibition efficiency for each concentration of inhibitor is calculated using Equation (1).

$\eta \%=\left[i^{\mathrm{o}}\right.$ corr $\left.-i_{\text {corr }}\right] / i^{\mathrm{o}}$ corr $\times 100$

where, $i^{\circ}{ }_{\text {corr }}$ and $i_{\text {corr }}$ are the corrosion current densities for copper electrode in the $0.5 \mathrm{M} \mathrm{HCl}$ solutions without and with inhibitors, respectively. 
Table 2. The corrosion parameters of the copper electrode in $0.5 \mathrm{M} \mathrm{HCl}$ solution free and containing different concentrations of PTP at $25{ }^{\circ} \mathrm{C}$

\begin{tabular}{|c|c|c|c|c|c|c|}
\hline Concentration, $\mathrm{mM}$ & $E_{\text {corr }}(\mathrm{mV} / \mathrm{SCE})$ & $i_{\text {corr }}\left(\mu \mathrm{A} / \mathrm{cm}^{2}\right)$ & $\beta_{\mathrm{c}}(\mathrm{mV} / \mathrm{dec})$ & $\beta_{\mathrm{a}}(\mathrm{mV} / \mathrm{dec})$ & $\Theta$ & $\eta(\%)$ \\
\hline 0 & -579 & 146.7 & 252.8 & -114.3 & - & - \\
\hline 1 & -428 & 43.7 & 168.2 & -151.7 & 0.70 & 70.2 \\
\hline 3 & -389 & 16.9 & 115.1 & -145.7 & 0.88 & 88.4 \\
\hline 5 & -349 & 11.7 & 129.1 & -162.5 & 0.92 & 92.0 \\
\hline 7 & -305 & 8.3 & 95.4 & -182.2 & 0.94 & 94.3 \\
\hline 10 & -303 & 6.8 & 102.7 & -186.3 & 0.95 & 95.4 \\
\hline
\end{tabular}

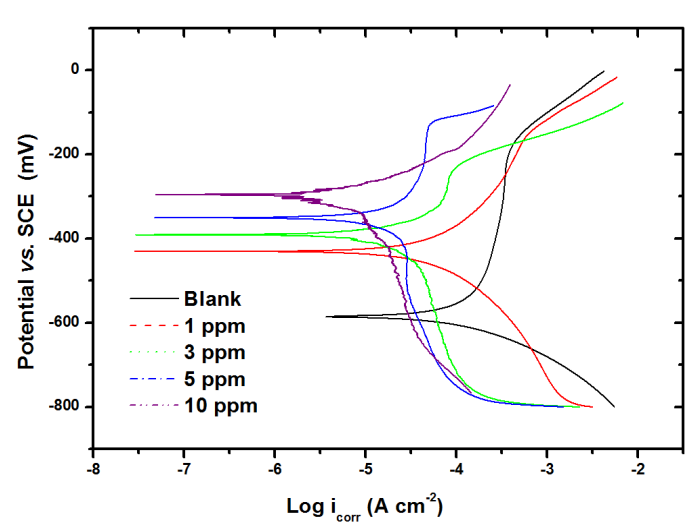

Figure 1. Potentiodynamic polarization curves for copper in $0.5 \mathrm{M} \mathrm{HCl}$ solution in the absence and presence of various concentrations of PTP at $25^{\circ} \mathrm{C}$.

It is clear from Table 2 that, the addition of inhibitor affects the anodic and cathodic reaction, and therefore the inhibitor acts as amixed-type inhibitor.

Also, the addition of organic inhibitor shifted the corrosion potential to positive value.Moreover, we note that the effect of PTP on both anodic and cathodic branches is pronounced which is a further enhancement of the corrosion inhibition with increasing concentration of PTP. This allows us to state that the adsorption of PTP takes place at both cathodic and anodic sites.

It is well known that the anodic reaction of copper is the dissolution of copper due to oxidation of $\mathrm{Cu}^{0}$ to $\mathrm{Cu}^{2+}$ and the reaction mechanism of copper has two steps in acidic chloride solution [31].The cathodic reaction is as follows:

$4 \mathrm{H}^{+}+\mathrm{O}_{2}+4 \mathrm{e}^{-} \rightarrow 2 \mathrm{H}_{2} \mathrm{O}$

According to Zhang et. al., [32] the overall reaction for copper corrosion in an acidic chloride solution is represented as:

$2 \mathrm{Cu}^{0}+4 \mathrm{Cl}^{-}+4 \mathrm{H}^{+}+\mathrm{O}_{2} \rightarrow 2 \mathrm{Cu}^{2+}+4 \mathrm{Cl}^{-}+2 \mathrm{H}_{2} \mathrm{O}$

In general, the inhibitor acted mainly as mixed-type inhibitors with a shift of $E_{\text {corrto }}$ more positive values. They all showed an inhibitive effect on anodic and cathodic reactions on copper surface.

\subsection{Electrochemical impedance spectroscopy measurements, EIS}

Electrochemical impedance spectroscopy (EIS) measurements were conducted to give more insight on the inhibition behavior of PTP on copper corrosion in $\mathrm{HCl}$ solution. Nyquist plots recorded for copper in $0.5 \mathrm{M} \mathrm{HCl}$ at open circuit potential (OCP), without and with various concentrations of the inhibitor are shown in Figure 2. In all cases, only on the depressed capacitive semicircle has been observed, indicating that corrosion of copper in uninhibited and inhibited solutions is under charge transfer control. These semicircles are assigned to the time constant of charge-transfer and to double layer capacitance. The semicircles at high frequencies are generally associated with the relaxation of the capacitors of electrical double layers with their diameters represents the chargetransfer resistances $[33,34]$. From these Nyquist plots, the values of the charge-transfer resistance, $R_{c t}$, were obtained from the difference in real component, $\mathrm{Z} /$, of impedance at lower frequencies. Also the double layer capacitances, $\mathrm{C}_{\mathrm{dl}}$, were calculated by $C_{\mathrm{dl}}=\left(2 \pi f_{\max } \mathrm{R}_{\mathrm{ct}}\right)$. Where $f_{\max }$ is the frequency value at which the imaginary component, $\mathrm{Z} / /$, of impedance is maximum. The experimental impedance results were fitted to theoretical values according to a simple equivalent circuit model consisting of a parallel combination representing the electrode capacitance, $C_{\mathrm{dl}}$, and the charge transfer resistance, $R_{\mathrm{ct}}$, in series with a resistor, $R_{\mathrm{s}}$, representing the ohmic drop in the electrolyte. According to ac circuit theory, an impedance plot obtained for a given electrochemical system can be correlated to one simple equivalent circuit. The impedance data of the copper electrode in the presence of inhibitor with different concentrations were analyzed using the equivalent circuit shown in Figure 3.

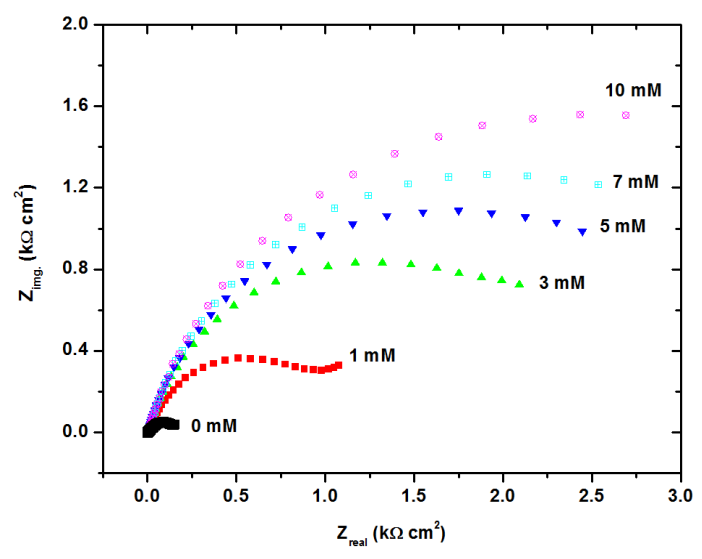

Figure 2. Nyquist diagrams for copper in $0.5 \mathrm{M} \mathrm{HCl}$ solution containing different concentrations of PTP at $25^{\circ} \mathrm{C}$.

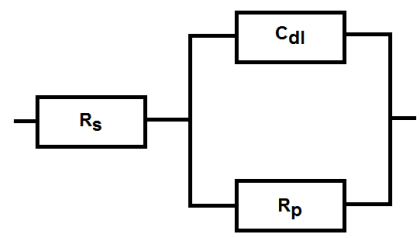

Figure 3. The equivalent circuit model used to fit the EIS experiment data.

From the Nyquist plots, the diameter of the semicircles increases with inhibitor concentration increasing. The calculated equivalent circuit parameters for $\mathrm{Cu}$ in $0.5 \mathrm{M}$ HClsolution containing different concentrations are presented in Table 3. The data reveal that the addition of the inhibitor to the $\mathrm{HCl}$ solution enhances the value of $R_{\text {ct }}$ (Cf. Table 3 and Figure 4) but reduces the value of $C_{\mathrm{dll}}$. 
Table 3. Equivalent circuit parameters for $\mathrm{Cu}$ electrode in $0.5 \mathrm{M} \mathrm{HCl}$ solution free and containing different concentrations of PTP at $25^{\circ} \mathrm{C}$.

\begin{tabular}{|c|c|c|c|c|}
\hline Concentration, $\mathrm{mM}$ & $R_{\mathrm{S}}(\Omega)$ & $R_{\mathrm{ct}}\left(\mathrm{k} \Omega \mathrm{cm}^{2}\right)$ & $C_{\mathrm{dl}}(\mu \mathrm{F} \mathrm{cm}-2)$ & $\alpha$ \\
\hline 0 & 2.1 & 0.20 & 1392 & 0.97 \\
\hline 1 & 8.3 & 1.73 & 123.6 & 0.99 \\
\hline 3 & 2.3 & 2.66 & 155.3 & 0.99 \\
\hline 5 & 2.4 & 3.45 & 153.9 & 0.99 \\
\hline 7 & 3.6 & 3.75 & 215.9 & 0.99 \\
\hline 10 & 7.6 & 4.87 & 224.6 & 1.0 \\
\hline
\end{tabular}

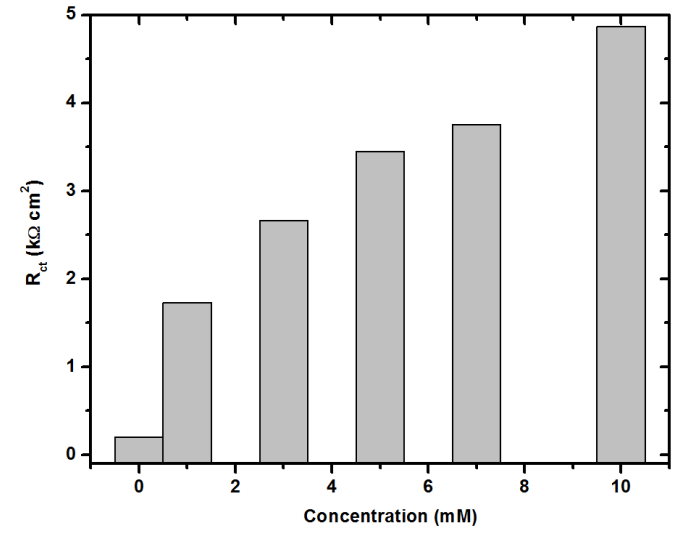

Figure 4. Variation of charge transfer resistance, $R_{\mathrm{ct}}$, with the concentration of inhibitor.

These changes in the impedance parameters increase with increasing the inhibitor concentration. The increase in the value of $R_{\mathrm{ct}}$ is ascribed to the adsorption of inhibitor molecules in the active center of the copper surface $[35,36]$. Such process may suggest the formation of protective film of inhibitor on the metal surface. This protective film impedes the charge-transfer across the metal/solution interface. On the other hand, the decrease in the value of $C_{\mathrm{dl}}$ could be related to a decrease in the local dielectric constant and/or an increase in the thickness of the electrical double layer, suggests that inhibitor acts by adsorption on the metal/solution interface [37,38]. This indicates that compound behaves as a remarkably efficient inhibitor. This result is in good agreement with the results of the potentiodynamic experiments.

\subsubsection{Scanning electron microscopic (SEM) analyses}

The surface morphology of a copper sample immersed in $0.5 \mathrm{M} \mathrm{HCl}$ for $10 \mathrm{~h}$ in the absence and presence of $10 \mathrm{mM}$ of PTP was studied by SEM and the experimental results are shown in Figure5, from which it can be seen that the surface copper sample before immersion seems smooth (Figure 5a). The copper specimen in the corrosive solution without inhibitor (Figure $5 \mathrm{~b}$ ) is strongly corroded by the medium, showing crystalline aggregates of the corrosion products on the surface and resulting in a porous and rough surface. In contrast, in the presence of the inhibitor (Figure $5 c$ ), there is much less damage on the copper surface, which further confirms the inhibition action. Therefore, it can be concluded that the PTP possesses good inhibiting ability for copper corrosion.

\section{Conclusions}

In conclusion, we have successfully developed a general method for the synthesis in excellent yields of Schiff bases 5a-c using nickel (II) nitrate hexahydrate as a catalyst. The structures of all the title compounds have been confirmed by NMR, IR, and HRMS. The studied Schiff base, 5c, PTP, is good inhibitor and act as the mixed-type inhibitors for copper corrosion in hydrochloric acid solution. Inhibition efficiencies increase by an increase in inhibitor concentration.

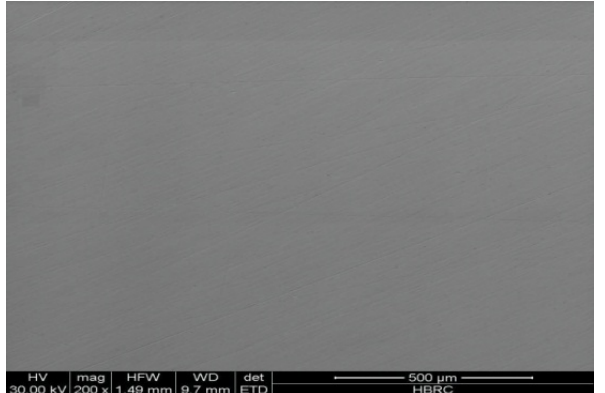

(a)

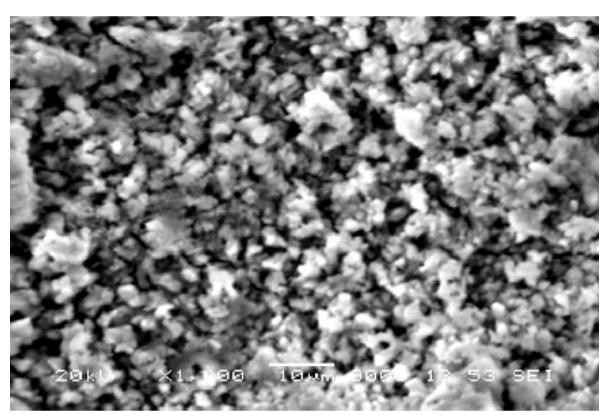

(b)

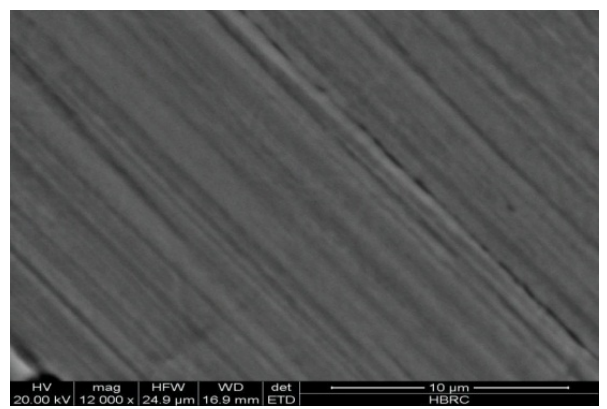

Figure 5. SEM micrographs of (a) freshly polished copper specimen, (b) the specimen immersed in $0.5 \mathrm{M} \mathrm{HCl}$ solution for $10 \mathrm{~h}$ at $25^{\circ} \mathrm{C}$ without PTP and (c) with $10 \mathrm{mM}$ PTP.

\section{References}

[1]. Sztanke, K.; Maziarka, A.; Osinka, A.; Sztanke, M. Bioorg. Med. Chem. 2013, 21, 3648-3666.

[2]. Alireza, A.; Zahra, A. Turk. J. Chem. 2013, 37, 867-878.

[3]. Abd El-halim, H. F.; Omar, M. M.; Mohamed, G. G. Spectrochim. Acta A 2011, 78, 36-44.

[4]. Khungar, B.; Rao, M. S.; Pericherla, K.; Nehra, P.; Jain, N.; Panwar, J.; Kumar, A. C. R. Chimie 2012, 15, 669-674.

[5]. Cezar, S.; Maria, P.; Cristian, T. Turk. J. Chem. 2008, 32, 487-493.

[6]. Atif, S. T.; Magda, N. A. N.; Magda, A. A. E; Samar, S. T. Med. Chem. Res. 2012, 21, 4139-4149.

[7]. Gehad, G. M.; Mohamed, M. O.; Ahmed, M. H. Turk. J. Chem. 2006, 30 361-382.

[8]. Omar, M. M.; Mohamed, G. G.; Ibrahim, A. A. Spectrochim. Acta A 2009, 73, 358-369.

[9]. Behpour, M.; Ghoreishi, S. M.; Salavati-Niasari, M.; Ebrahimi, B. Mater Chem. Phys. 2008, 107, 153-157.

[10]. Aytac, H. U.; Ozmen, U.; Kabasakaloglu, M. Mater. Chem. Phys. 2005 89, 176-181. 
[11]. Behpour, M.; Ghoreishi, S. M.; Soltani, N.; Salavati-Niasari, M.; Hamadanian, M.; Gandomi, A. Corros. Sci. 2008, 50, 2172-2181.

[12]. Ashassi-Sorkhabi, H.; Shaabani, B.; Seifzadeh, D. Appl. Surf. Sci. 2005, 239, 154-164.

[13]. Ahamad, I.; Prasad, R.; Quraishi, M. A. Mater. Chem. Phys. 2010, 124, 1155-1165.

[14]. Mohamed, H. A.; Farag, A. A.; Badran, B. M. J. Appl. Poly. Sci. 2010, 117, 1270-1278.

[15]. Finsgar, M. Corros. Sci. 2013, 77, 350-359.

[16]. Pan, Y. C.; Wen, Y.; Zhang, R.; Wang, Y. Y.; Zhang, Z. R.; Yang, H. F. Appl. Surf. Sci. 2012, 258, 3956-3961.

[17]. Kovacevic, N.; Kokalj, A. Corros. Sci. 2013, 73, 7-17.

[18]. Sudheer, M. A. Corros. Sci. 2013, 70, 161-169.

[19]. Dermaj, A.; Hajjaji, N.; Joiret, S.; Rahmounia, K.; Srhiri, A.; Takenouti, H.; Vivier, V. Electrochim. Acta 2007, 52, 4654-4662.

[20]. AppaRao, B. V.; Narsihma, R. M.; Sreedhar, B. Prog. Org. Coat. 2014, 77, 202-212.

[21]. Fouda, A. S.; Wahed, H. A. Arab. J. Chem., doi: 10.1016/j.arabjc.2011.02.0.

[22]. Vera, R.; Bastidas, F.; Villarroel, M.; Oliva, A.; Molinari, A.; Ramirez, D.; del Rio, R. Corros. Sci. 2008, 50, 729-736.

[23]. Dafali, A.; Hammouti, B.; Touzani, R.; Kertit, S.; Ramdani, A.; El Kacemi, K. Anti-Corr. Meth. Mater 2002, 49, 96-104.

[24]. Safak, S.; Duran, B.; Yurt, A.; Turkoglu, G. Corros. Sci. 2012, 54, 251259.

[25]. Emregul, K. C.; Atakol, O. Mater. Chem. Phys. 2004, 83, 373-379.

[26]. Streitwieser, A.; Heathcock, C. H.; Kosower, E. M. Introduction to Organic Chemistry, Prentice Hall, New Jersey, USA, 1998.

[27]. Chakraborti, A. K.; Bhagat, S.; Rudrawar, S. Tetrahedron Lett. 2004, 45, 7641-7644.

[28]. Da Silva, C. M.; Da Silva, D. L.; Modolo, L. V.; Alves, R. B.; De Resende, M. A.; Martins, C. V. B.; De Fatima, A. J. Adv. Res. 2011, 2, 1-8.

[29]. Soderberg, T. Organic Chemistry with a Biological Emphasis, University of Minesota, Moris, 2012.

[30]. Hajjaji, N.; Rico, I.; Srhiri, A.; Lattes, A.; Soufiaoui, M.; Bachir, B. Corros. 1993, 49, 326-334.

[31]. El-Sayed, M. S.; Erasmus, R. M.; Comins, J. D. J. Colloid Interf. Sci. 2007, 311, 144-151.

[32]. Zhang, D. Q.; Gao, L. X.; Zhou, G. D. J. Appl. Surf. Sci. 2004, 225, 287-293.

[33]. Sherif, E. M.; Park, S. M. Electrochim. Acta 2006, 51, 4665-4673.

[34]. Ma, H.; Chem, S.; Niu, L.; Zhao, S.; Li, S.; Li, D. J. Appl. Electrochem. 2002, 32, 65-72.

[35]. Mansfield, F. Corrosion Mechanisms, Marcel Dekker, New York, 1987.

[36]. El-Hafez, G.; Badawy, W. A. Electrochim. Acta 2013, 108, 860-866.

[37]. Hamed, E. Mater. Chem. Phys. 2010, 121, 70-76.

[38]. El-Haddad, M. N. Int. J. Biol. Macromol. 2013, 55, 142-149. 